\title{
Product Innovation, Price Level And Competitive Advantage: A Perception Assessment Of Beer Products
}

\author{
Agaba Moses ${ }^{1 *}$, Emenike Kalu $\mathbf{O}^{1}$, Olutayo Osunsan ${ }^{1}$ \\ ${ }^{1}$ Kampala International University, Uganda \\ *agabamosez@yahoo.com
}

\begin{abstract}
This study evaluates the effect of product innovation and prices on competitive advantage of beer products in Kabale Uganda, by analyzing responses obtained through questionnaires using multiple regression analysis. From analysis of respondents, the percentage of targeted respondents that actually responded to the questionnaire was $96 \%$. From the preliminary analysis conducted in this study, majority of respondents have the following attributes,1 ) diploma level education, 2) are males, 3) aged between 36-45 years, and 4) prefer Nile lager beer. The data approximates normal distribution, with absence of multicollinearity. The results of the multiple regression analysis indicate that product innovation and prices have significant effect on competitive advantage among beer products and producers in Kabale Uganda. We therefore conclude that innovation and prices have positive and significant predictive effect on competitive advantage. Hence, the firms could enhance competitive advantage by paying attention to innovation and prices variables. We therefore recommend, amongst others, that that brand managers should prioritize innovation and prices as strategies to attract and sustain competitive advantage.
\end{abstract}

Keywords: Competitive Advantage, Product Innovation, Price Level

\section{INTRODUCTION}

The importance of competitive advantage to sustainability of business firms in today's globalised economy has been established. Competitive advantage, according to Naatu (2016), is the tool that enables a company to take a larger market share and generate more sales. It is an advantage gained over competitors by offering customers higher value, either through lower prices or by providing additional benefits and services that justify similar or possibly higher prices. Advantage falls into only two categories, something that you own that is a barrier to competition or something that you do very well that effectively bars competitors. So competitive advantage is somehow correlated with value added and the constructs of confidence in the purchase decision, efficiency and effectiveness of marketing programs, higher profitability and differentiation have been used to measure competitive advantage. Competitive advantage, in the opinion of Porter (2008) is a key determinant of superior performance that ensures survival and prominent placing in the market. Given that every firm desires to be a going concern, competitive advantage becomes a sustainability factor to modern business firms. Hence every firm is desirous of entrenching competitive advantage in the product or services it delivers to the market.

Product innovation, prices and technological advancement are main 
components of competitive strategy for many manufacturing firms (Mesquita, Lazzarini, \& Cronin, 2007). Most firms face serious competitive challenges due to the rapid pace and unpredictability of technology change and failure to utilize innovation as a competitive advantage. Others argue that the advantages of managerial innovations, such as the strategic management of human resources, or information-based innovations, such as new market research techniques, provide more durable routes to competitive positioning that can be gained from product innovations. Knox (2002) opines that firms could only specialize in developing technologies that have pivotal importance to their business in order to protect imitability of key competitive elements. The common thread is identifying outcomes that are difficult for other firms to replicate. He (2012) argues that firms must provide the same services or products as its competitors, but at a lower cost. While product differentiation occurs when a firm produces a product or service that is preferred by buyer and this can happen by improving the quality of the product or services better than its competitors, or providing innovative products or services that are not offered by its rivals. Competitive advantage could therefore manifest through changes in the products, changes in the processes, new distribution forms, and changes in price level.

Many studies have focused on the relationship between competitive advantage and other variables which can be expected to lead to superior market place performance such as enhanced market share, customer satisfaction and financial performance (see for example, Mwangi, Kamau \& Mainan, 2007; Zipporah, 2013; Joonas, 2013; Naatu, 2016; Tobias, 2017). These studies concentrated on the nexus between product brand building and competitive advantage. None of these studies were conducted in Uganda nor concentrated on alcoholic products. More so, little attention has been given to innovation and piece levels as sources of competitive advantage. Hence there is need to address this gap in the literature by investigating the effect of product innovation and price levels as new dimension and as antecedent of competitive advantage among beer products in Uganda.

The objective of this paper is to analyze the effect of product innovation and price level on competitive advantage among alcoholic beer products and producers in Kabale District in South Western Uganda. The findings of this study are important to existing and prospective alcoholic beer producers in Uganda, regulators of alcoholic products, and to future researchers. The producers of alcoholic products, for example, will understand how innovation and prices drive competitive advantage. The regulators will gain better insight into regulation of prices and innovation so as to sustain alcoholic products industry. The findings will further enrich existing knowledge on interaction between innovation, prices and competitive advantage as well as provide literature for future researchers of related subject. The remainder of this paper organized as follows: Section 2 contains review of related literature. Section 3 describes the data and method for analysis. Section 4 presents results and discussions, and section 5 provides conclusions and recommendations.

Numerous empirical studies have been conducted to identify the drivers of competitive advantage. According to Tidd et al. (2006), innovation contributes to achieving a competitive advantage in several aspects. The most important characteristics of innovations include: a strong relationship between market performance and new products. Innovation of processes that lead to production time shortening and speed up new product development in comparison to competitors. Developing successful technological innovations, therefore, is essential for creating and sustaining an organization's competitive advantage

Kamiri (2006) examined the creation and application of brand equity in insurance companies in Kenya. The survey was conducted on 30 insurance companies 
operating in Nairobi. It was found that application of brand equity is well pronounce in insurance product where image is created through formation of attachment between the brand name and quality. A later study by Maina (2007), examine the variables that determine brand loyalty in the toothpaste industry In Kenya. The study was carried out on three toothpaste brands including Aquafresh, Colgate and Close-Up. They found that, some multivariate measurements including customers' perceived value, brand trust, customers' satisfaction, repeat purchase behavior, and commitment are key factors influencing of brand loyalty. The other factors like price, brand names, time, and first entrants were also found carry an influence on brand loyalty.

The most usual causes of innovation which drive competitive advantage, according to Porter (1990), are: new technologies, new or shifting buyer needs, the emergence of a new industry segment, shifting input costs or availability, changes in government regulation. According to the study by Hana (2013), on competitive advantage achievement through innovation and knowledge, all organizations agree that innovations and innovative activities are important. It is possible to say that both small and large organizations generally follow the same goals in the area of innovative activities. All organizations, regardless of their size, strive to obtain, by means of successful innovations, a significant and, if possible, long-term and sustainable competitive advantage and finally convert it into better financial results. At present, any organization that wishes to maintain its position in the market has to make innovations.

According to the study carried out by Musia (2013) on factors influencing the competitive advantage by east African breweries ltd within beer manufacturing sector in Kenya. A company has a competitive advantage whenever it has an edge over its competitor in securing customers and defending itself against competitive forces. The study concludes that competitive advantage is rise out of core competencies that yield the long term benefit to the company.

In a related study, Naatu (2016) examine brand building for competitive advantage in the Ghanaian jewelry industry. The results determine that research and development, internal branding, brand positioning/promotion and customer orientation are the important branding factors for competitive advantage adopted by the firms. Syarifuddin (2017) observes that in building advantage, it is recommended to form a unique system as well as provide good value for customers efficiently. He concluded amongst others that cost advantage strategy is major factor in sustaining competitive strategy.

Tobias (2017) investigates the effect of price promotions' influence and discountstore distribution on brand equity differs for different types of brands. The results reveal that frequent price promotions and intensive discount-store distribution have a negative influence on brand equity. However, this effect differs across brand types: the higher a brand's initial equity level, the more harmful is the impact of these marketing activities on brand equity. He concluded that Managers of high-equity brands should avoid frequent price promotions and intensive discountstore distribution. In contrast, managers of low-equity brands may use these instruments more widely because their detrimental effects are less.

To achieve the objectives of this study, the following hypotheses were tested:

Ho1: Product innovation does not have significant effect on competitive advantage among alcoholic beer products.

Ho2: Price level does not significantly affect competitive advantage among alcoholic beer products.

\section{METHOD}

This study was conducted using primary data. The primary data were collected self-administered questionnaires distributed to producers, wholesalers, 
retailers and consumers of alcoholic beverages in Kabale District, Uganda. The questionnaire was selected as an instrument to collect the data because it is straight forward and less time consuming for respondents. The questionnaires were structured and were administered through drop and pick later method.

The target population of the study was the locally 1783 including wholesalers, retailers, customers and brand and marketing managers of Nile Special Lager, Eagle Lager, Senator Extra Lager, club and Consumers of unbranded beer products in the Kabale District. The sample size was determined using the Slovene's formula below :

$n=\frac{N}{1+N(\alpha)^{2}}$

Where; $\mathrm{n}=$ sample size; $\mathrm{N}=$ target population; $\alpha=0.05$ level of significance.

$n=\frac{1783}{1+1783(0.05)^{2}}$

$n=\frac{1783}{1+1783(0.0025)}$

$n=\frac{1783}{1+4.5}$

$n=\frac{1783}{5.5}$

$n \cong 324$

Therefore the minimum sample size chosen in this study was 324 respondents. Multistage sampling techniques were used in this study. Simple random sampling technique was used to select alcoholic beverages products and producers. Purposive sampling technique was adopted to sample shopping center to collect consumer information. Shopping centers were selected based on a marketing investigation. The choice criterion was that the clubs/bars receive more than 20 customers per day. A total of 84 hotels, restaurants and bars were chosen for the study and in each of the hotels, restaurants, clubs and bars, 2 customers and 1 manager were chosen for the survey. This is in line with Nworgu (1991) who stated that no fixed number is ideal, rather it is the circumstances of the study situation that determine what number or what percentage of the population that should be studied.

\section{Validity of Research Instrument}

To ensure the validity of the questionnaire, expert opinion and content validity index (CVI) were used. The instrument was validated by four experts: Two experts in measurement and evaluation and two content experts. The four experts measured the face validity of the instrument, ensuring that the item/statements addressed the research purposes and questions, as well as the adequacy of the constructs used in the questionnaire. All their criticisms, corrections and suggestions gave birth to the final copy of the instrument used for data collection. The content validity index (CVI) was computed to determine the content validity of the instrument. Amin (2005) notes that the overall CVI for the instrument should be calculated by computing the average of the instrument and for the instrument to be accepted as valid the average index should be 0.70 or above. The CVI was computed in equation below. The CVI was estimated as follows:

$$
C V I=\frac{\text { Number of questions declared valid }}{\text { Total number of questions }}
$$

$$
\begin{aligned}
C V I=\frac{79}{84} \\
C V I=0.94
\end{aligned}
$$

A CVI value of 0.94 is greater than 0.7 minimum CVI required for a valid instrument. Hence the instrument is valid. 


\section{Reliability of Research Instrument}

In order to ensure that the research instrument is reliable and can consistently produce reliable data when administered, the researchers adopted are test-retest, split half and Cronbach's alpha. The test-retest reliability method measures the stability of the research instrument. It intends to determine the extent to which a measure, procedure or instrument yields the same result on repeated trials. This was done by administering the research instrument twice on the same set of respondents at different times. The questionnaire was given to 30 respondents. Same instrument was readministered to the respondents after two weeks. Data collected from the two intervals were estimated with correlation coefficients (Pearson $r$ ). Hence a reliability coefficient of 1.76 was obtained and presented in Table 1. This indicates that the instrument was reliable for the study. According to Maduabum (2004), an instrument is considered reliable when it has a coefficient ranging from 0.60-0.99. Split-half method measures the internal consistency of the instrument. In this method, research instrument was split into two equivalent halves and the test score correlated together (Oyerinde, 2011). This study employed split halves method to measure the degree to which the items that made up the scale were all measuring the same essential attribute. This was estimated with correlation coefficients (Pearson $r$ ) and Cronbach's coefficient alpha. Correlation coefficients range from 0.00 to 1.00 . Correlation coefficient of 0.00 means no correlation, while correlation coefficient of 1.00 means perfect correlation. The results of the splithalf presented in Table 1 indicate that the instrument was reliable for the study. Similar to the test re-test and split-half methods, Cronbach's coefficient alpha is the measure of scale's internal consistency. A Cronbach's alpha coefficient greater than 0.7 , is commonly acceptable, as a rule of thumb, as internal consistency of research instrument. As can be seen in the results of the reliability tests presented in Table 1, the Cronbach's alpha coefficient is 0.934 , and indicates that the instrument is very reliable. Split-half test and other tests were meant to corroborate Cronbach's coefficient alpha. Split-half reliability test gives a value of 0.886 and 0.884 for each of the two halves respectively. Correlation Between Forms is 0.870; Spearman-Brown Coefficient Equal length is 0.824 and unequal length is 0.824 and Guttman Split-half 0.823. Each and every one of these tests shows that the instrument is very reliable.

Table 1: Results of Reliability Tests for the Survey Scale

\begin{tabular}{|c|c|c|c|}
\hline Number & $\begin{array}{l}\text { Type of } \\
\text { Reliability } \\
\text { Test }\end{array}$ & Value & Remarks \\
\hline 1 & $\begin{array}{l}\text { Cronbach's } \\
\text { Alpha }\end{array}$ & 0.929 & Very Reliable \\
\hline 2 & $\begin{array}{l}\text { Split-half } \\
\text { Correlation }\end{array}$ & $\begin{array}{l}\text { Part } 1=0.886 \\
\text { Part } 2=0.884\end{array}$ & $\begin{array}{l}\text { Very Reliable } \\
\text { Very Reliable }\end{array}$ \\
\hline 3 & $\begin{array}{l}\text { Between } \\
\text { Forms }\end{array}$ & 0.870 & Very Reliable \\
\hline 4 & $\begin{array}{l}\text { Spearman- } \\
\text { Brown } \\
\text { Coefficient } \\
\text { Guttman Split- }\end{array}$ & $\begin{array}{l}\text { Equal } \\
\text { Length=0.824 }\end{array}$ & Very Reliable \\
\hline & & 0.823 & Very reliable \\
\hline
\end{tabular}

Source: Field Study 2017

\section{Method of Data Analysis}

To establish the effect of product innovation and price level on competitive advantage among beer products and producers in Kabale Uganda, we conducted multiple regression analysis below:

$Y=\beta_{0}+\beta_{1} X_{1}+\beta_{2} X_{2}+\mu$

Where,

$\mathrm{Y}=$ independent variable,

$\beta_{0}=$ intercept of $\mathrm{Y}$,

$\beta=$ parameter of the dependent variables, and $\mathrm{u}=$ error term.

To estimate the multiple regression models, it was converted as follows:

$\mathrm{CA}=\beta_{0}+\beta_{1} \mathrm{PI}+\beta_{2} \mathrm{PL}+\mu$ 
Where:

$\mathrm{CA}=$ Competitive advantage

$\mathrm{Bo}=$ Constant or Intercept

$\beta_{1}=$ Coefficient of Product innovation

$\beta_{2}=$ Coefficient of Price level

$\mu=$ Error term

$\mathrm{PI}=$ Product innovation

$\mathrm{PL}=$ Price level

The sign of the slope coefficients ( $\beta_{1}$ and $\beta_{2}$ ) was used to establish the effect of product innovation and price level on competitive advantage among beer products and producers in Kabale Uganda. Positive and significant slope coefficients would indicate that the product innovation and price level have positive effect on competitive advantage among beer products and producers in Kabale Uganda. Negative and significant slope coefficients, on the other hand, would indicate that product innovation and price level have negative effect on among beer products and producers in Kabale Uganda. The a priori expectation of the slope coefficients are as follows: $\beta_{1}, \beta_{2}>$ 0 . All the tests were tested at the five percent (5\%) significance level.

\section{RESULTS AND DISCUSSION \\ Result \\ Response Rate and Demographic Characteristics of Respondents}

Response rate is usually conducted to ascertain the percentage of the targeted respondents that actually responded to the questionnaire. From the results presented in Table 2, notice that out 324 targeted respondents who were given questionnaires, 312 of them filled and returned the questionnaires. This represents a response rate of $96 \%$. This percentage was considered high and good enough to represent the target population, given the busy schedule of the targeted population. This high response rate was achieved due to marking-up of the minimum sample size by $20 \%$ (64), which resulted in distributing 388 questionnaires. The essence of the mark-up is to minimize the problem associated with non-return of questionnaire by some respondents. The questionnaires returned from the field were assessed and found to be duly completed for use in this study.

Table 2. Response Rate

\begin{tabular}{lll}
$\begin{array}{l}\text { Targeted } \\
\text { respondents }\end{array}$ & $\begin{array}{l}\text { Actual } \\
\text { respondents }\end{array}$ & $\begin{array}{l}\text { Responses as } \\
\text { percentage of } \\
\text { targeted } \\
\text { respondents }\end{array}$ \\
\hline 324 & 312 & $96 \%$ \\
\hline r
\end{tabular}

Source: Response rate analysis (2017)

The study presents the demographic profiles of the respondents in Table 3. From the Table 2, notice that majority of the respondents were males with $80.1 \%$, and $19.93 \%$ of the respondents were females. The gender of respondents shows that more males consume alcoholic beverages in Kabale, Western Uganda. It also shows that the finding of the study does not suffer from gender bias.

Notice also, from Table 2, that that majority of the respondents were aged between 36 - 45 years of age (37.8\%), followed by those aged between 46-55 (26.3\%). The least of the respondent were those aged between $18-24$ years (4.5\%). These indicate that the respondents were adults.

The study requested the respondents to indicate their level of education. Notice from Table 3 that diploma education is the level of education with the highest response rate. From the table, $36.2 \%$ of the respondents indicated their highest education level as diploma. This is followed by bachelors and certificate education, with $30.8 \%$ and $17.3 \%$ respectively. The respondents with masters' degree are the least sampled with 5.1\% response rate. Table 2 indicates that all of the respondents sampled in this study have formal education.

Data was collected from the respondent on their beer brand. From Table 3, see that majority of the respondents take Nile beer (29.5\%), closely followed by Club beer with respondents rate of $27.9 \%$. The least brand of alcohol consumption according to the 
respondents was local beer with a 9.3\% response rate. These imply that Nile beer is the favorite for respondents sampled.

Table 3. Respondent demographic characteristics

\begin{tabular}{|c|c|c|c|}
\hline Variables & Category & Frequency & Percent \\
\hline \multirow[t]{3}{*}{ Gender } & Male & 250 & 89.1 \\
\hline & Female & 62 & 19.9 \\
\hline & Total & 312 & 100.0 \\
\hline \multirow{6}{*}{ Age } & $18-24$ & 14 & 4.5 \\
\hline & 25-35 & 73 & 23.4 \\
\hline & $36-45$ & 118 & 37.8 \\
\hline & $46-55$ & 82 & 26.3 \\
\hline & $\begin{array}{l}55 \text { and } \\
\text { above }\end{array}$ & 25 & 8.0 \\
\hline & Total & 312 & 100 \\
\hline \multirow[t]{6}{*}{$\begin{array}{l}\text { Education } \\
\text { level }\end{array}$} & $\begin{array}{l}\text { High } \\
\text { school }\end{array}$ & 33 & 10.6 \\
\hline & Certificate & 54 & 17.3 \\
\hline & Diploma & 113 & 36.2 \\
\hline & Bachelors & 96 & 30.8 \\
\hline & Masters & 16 & 5.1 \\
\hline & Total & 312 & 100 \\
\hline Beer & Eagle & 70 & 22.4 \\
\hline \multirow[t]{5}{*}{ Brand } & Nile & 92 & 29.5 \\
\hline & Club & 87 & 27.9 \\
\hline & Senator & 34 & 10.9 \\
\hline & Bell & 29 & 9.3 \\
\hline & Total & 312 & 100 \\
\hline
\end{tabular}

Source: Authors' computation

\section{Analysis of Multicollinearity in Product} Innovation and Price Level Variables

Multicollinearity exists whenever two or more of the predictors in a regression model are moderately or highly correlated. It is a state of very high intercorrelations or inter-associations among the independent variables. It is therefore a type of disturbance in the data, and if present in the data the statistical inferences made about the data may not be reliable. The presence of multicollinearity in study was evaluated using Tolerance levels and the Variance Inflation Factor (VIF). The decision rule for the Tolerance level is to accept absence of multicollinearity if the tolerance level is greater than 0.5. Similarly, there is absence of multicollinearity if the VIF if less than 3. Notice from the Table 4 that the Tolerance level is greater than 0.5 in both product innovation and price level variables. These indicate evidence of absence of multicollinearity in the predictor variables. Similarly, coefficients of the VIF are less than 3 for all brand equity variables. Hence, provide support for the absence of multicollinearity shown by the Tolerance level. Consequently, there is no existence of multicollinearity in the predictor variable. They are therefore good for empirical analysis.

Table 4. Collinearity Statistics

\begin{tabular}{lll}
\hline Construct & Tolerance & VIF \\
\hline Product & & \\
& 0.673 & 1.487 \\
Fnnovation & 0.651 & 1.536 \\
\hline
\end{tabular}

Source: author's computation (2017)

Effect of Product Innovation and Price Level on Competitive Advantage of Beer Products and Producers in Kabale Uganda

Notice from Table 5 that product innovation and price level have significant positive and significant effect on competitive advantage among alcoholic beverages products and producers in Kabale Uganda at the $5 \%$ percent significance level. These are glaring from the significance of the $t$-statistic for product innovation (4.6) and price level (5.2) which are greater than the theoretical $t$ statistic (1.96), and the $p$-value for product innovation (0.00) and price level (0.00) which are both less than the study significance level (0.05). Consequently Ho1 and $\mathrm{Ho}_{2}$ were rejected. These results indicate positive effect of product innovation and price level on competitive advantage among alcoholic beverages products and producers in Kabale Uganda

The estimates of the regression model further shows that $R^{2}$ is 0.27 . This indicates that $27 \%$ of the total variation in competitive advantage is accounted for by product innovation and price level. The F-statistics indicate that the two coefficients (price level, and product innovation), excluding constant, are not zero. This is evident in the $p$-value 
(0.00) of $f$-statistics is less than the critical value (0.05). More so, the Durbin-Watson coefficient (1.98) indicates that there is absence of serial correlation in the residual of the regression estimate.

Table 5. Results of the effect of product innovation and price level on competitive advantage of beer products and producers in Kabale Uganda

\begin{tabular}{lllll}
\hline Variable & B & $\begin{array}{l}\text { Std. } \\
\text { erno }\end{array}$ & t-stat. & p-value \\
\hline Constant & 2.215 & .136 & 16.303 & 0.000 \\
Product & 0.183 & .039 & 4.668 & 0.000 \\
Innovation & & & & \\
Price Level & 0.198 & .038 & 5.240 & 0.000 \\
\hline \hline
\end{tabular}

$\mathrm{R}=0.52 ; \mathrm{R}^{2}=0.27$; Durbin-Watson=1.98; $\mathrm{F}(2,309)$ $=55.72[0.00]$

Source: author's computation (2017)

\section{Discussion}

The study set up to evaluate the effect of product Innovation and price Level on competitive advantage in alcoholic beverage products. The results indicate that product innovation and price level have significant positive and significant effect on competitive advantage among in alcoholic beer products at the $5 \%$ percent significance level, as shown in Table 5. These results are in agreement with Hana (2013) and Tobias (2017). Hana (2013), in her study of competitive advantage and innovation and knowledge, highlight the importance of innovations and innovative activities are important. She shows that both small and large organizations generally follow the same goals in the area of innovative activities. All organizations, regardless of their size, strive to obtain, by means of successful innovations, a significant and, if possible, long-term and sustainable competitive advantage and finally convert it into better financial results. At present, any organization that wishes to maintain its position in the market has to innovate. She concludes, amongst others, that all organisations think that innovations and innovative activities are important. Hence her conclusion supports the results of this study on the effect of product innovation on competitive advantage among beer products in Kabale District. Similarly, Njuguna (2017) indicates that the effect of product innovation positively and significantly influences competitive advantage of youth enterprises in Kenya, hence supporting the results on effect of product innovation on competitive advantage in alcoholic beer products.

The results from the study carried out by Hahle (2016), support the findings on price levels and competitive advantage among alcoholic beer products by indicating that price levels have positive effect on competitive advantage. In a similar study, Tobias (2017) relates price level to brand equity, and concluded that managers of highequity brands should avoid frequent price promotions and intensive discount-store distribution. In contrast, managers of lowequity brands may use these instruments more widely because their detrimental effects are less severe.

\section{Conclusion}

This study evaluated the effect of product innovation and price level on competitive advantage in beer and producers products in Kabale Uganda, by evaluating responses obtained through questionnaires using multiple regression analysis. From analysis of respondents, the percentage of targeted respondents that actually responded to the questionnaire was $96 \%$. From the preliminary analysis conducted in the study, majority of respondents in this study have the following attributes, 1) diploma level education, 2) are males, 3 ) aged between 3645 years, and 4) prefer Nile lager beer. The data approximates normal distribution, with absence of multicollinearity. The estimates from the multiple regression analysis suggest that product innovation and price level have positive and significant effect on competitive advantage among alcoholic beer products and producers in Kabale Uganda. This is evident in the statistical significance of the product innovation and price level coefficients at the $5 \%$ significant. We 
therefore conclude that product innovation and price level has positive and significant predictive effect on competitive advantage. Hence, firms could enhance competitive advantage by paying attention to product innovation and price level.

We therefore recommend that that brand managers should prioritize innovation and prices as strategies to attract potential customers because of their significant effect on competitive advantage. Marketing and brand managers of alcoholic products should appreciate the important roles of product innovation and prices as major determinant of competitive advantage.

\section{REFERENCES}

Amin, E.M. (2005). Social Science Research: Conception, Methodology And Analysis. Kampala: Makerere University of Printery.

Hana, U. (2013). Competitive Advantage Achievement Through Innovation And Knowledge. Journal of Competitiveness, 5(1), 82-96.

He, N. (2012). How To Maintain Sustainable Competitive Advantage: Case Study On The Evolution Of Organizational Strategic Management. International Journal of Business Administration, 3 (5) 45-46.

Knox, S. (2004). Positioning And Branding Your Organization. Journal of Brand and Product Management, 13(2), 105115.

Maina, M. F. (2007). An Investigation Of Factors Influencing Brand Loyalty: The Case Of Tooth Pastes Brands In Kenya. MBA Thesis, University of Nairobi Kenya.

Mesquita, L. F., Lazzarini, S. G., \& Cronin, P. (2007). Determinants Of Firm Competitiveness In Latin American Emerging Economies: Evidence From Brazil's Auto Parts Industry. International Journal of Operations and Production Management, 27(5), 501-503.
Musia, Z. M. (2013). Factors Influencing Competitive Advantage By East African Breweries Ltd within beer manufacturing sector in Kenya. MBA Thesis, University of Nairobi Kenya

Naatu, F. (2016). Brand Building For Competitive Advantage In The Ghanaian Jewelry Industry. International Review of Management and Marketing, 2016, 6(3), 551-558.

Njuguna, S. M. (2017). Effect Of Strategic Management Options On Competitive Advantage Of Youth Enterprises In Kenya. Unpublished $P h D$ Thesis in Business Administration, Jomo Kenyatta University of Agriculture and Technology.

Oyerinde, D. T. (2011). Value Relevance Of Accounting Information In Nigeria. PhD Thesis Submitted to Postgraduate School, Covenant University Nigeria.

Porter, M. (1990). Competitive Advantage: Creating And Sustaining Superior Performance. NewYork: Macmillan.

Porter, M.E. (2008). The Five Competitive Forces That Shape Strategy. Harvard Business Review, 79-93.

Ren, L., Xie, G., \& Krabbendam, K. (2010). Sustainable Competitive Advantage And Marketing Innovation Within Firms: A Pragmatic Approach For Chinese Firms. Management Research Review, 33(1), 79-89.

Shiffman, L.G. \& Kanuk, L.L. (2009). Consumer Behaviour (9th ed). New Jersey USA: Pearson Education Inc.

Syarifuddin, D. (2017). Competitive Advantage On Hotel Industry In Pekanbaru Indonesia. International Business Management, 11(2), 397-406.

Tobias K. (2017). Price Promotions And Brand Equity: The Role of Brand Types. Econstor. Retrieved online: http://hdl.handle.net/10419/157296. 